\title{
Response of Sweet Pepper to The Application of Mineral Fertilizers Mixed with Bio-Fertilizers
}

Ahmed, M. E. M

Department of Horticulture, Faculty of Agriculture, Tanta University, Tanta, Egypt. dr.memahmed@agr.tanta.edu.eg

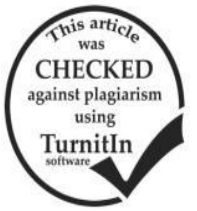

\begin{abstract}
Two greenhouse experiments were conducted at the experimental farm of the Faculty of Agriculture, Tanta University, Tanta, Egypt, during 2013/2014 and 2014/2015 seasons. The aim of this research is to study the effect of different levels of mineral fertilizers $(50,75$ and $100 \%$ of recommended dose 'RD') with some bio-fertilizers, i.e. Easterna biofert (commercial bio-fertilizer) and a mixture of Rhizobacterin, Phosphorein and Potassiumage on the growth, yield and fruit quality of sweet pepper plants (Capsicum annuum, L. cv. Gideon F1 hybrid). The experiment was designed in a completely randomized blocks (CRB) with four replicates. Results indicated that the maximum vegetative growth parameters, yield, fruit quality, and chemical composition of the plant leaves and fruits were recorded a result of the following treatments in descending order; application of $100 \%$ of RD of mineral fertilizer; $75 \%$ RD of mineral fertilizer mixed with phosphorein, potassiumage and rhizobacterin; 75\% RD of mineral fertilizer combined with Easterna biofert; however there were no significant differences among these treatments. Application of 50\% RD of mineral fertilizer with the bio fertilizers mixture, or with easterna biofert only was significantly reduced those parameters. It could be concluded that fertilizer mix of mineral fertilizes at $75 \% \mathrm{RD}$ combined with phosphorein, potassiumage and rhizobacterin, or with easterna biofert only can improve the productivity and fruit characteristics of sweet pepper under greenhouse conditions. In addition to that, mixing mineral fertilizers with biofertilizers reduce the cost of chemical fertilizer, nitrate accumulation in the edible portion that affect human health, and environmental pollution.
\end{abstract}

Keywords: Sweet pepper, bio, mineral-fertilizers, Vegetative growth, yield, chemical contents.

\section{INTRODUCTION}

Sweet pepper is one of the most popular vegetable crop in Egypt. The annual yield can be locally used or for exportation. It has an important nutritional and monetary value worldwide. (Rajput and Poruleker, 1998).

Fruit growth and development is basically affected by applied fertilization program throughout the season; although fertilizers cost is considered a major part of the total cost of sweet pepper under greenhouses conditions. Moreover, fertilizers negatively affect the ecosystem and soil fertility (Lyons et al., 1994). To reduce these negative effects, the use of chemical fertilizers should be minimized, in addition to developing some other field management strategies, for example optimizing the rate of used fertilizers at the levels that only meet the actual plant need (Singh et al., 2007 and Hassan et al., 2012), and may be replacing them with other bio-fertilizers, such as those contains bacterial species, especially those associated with plant rhizosphere that significantly affect plant growth. The use, of biofertilizers to improve plant growth, as alternative of chemical fertilizers has been attracted many researchers for years (Rodriguez and Fraga, 1999; Hassan, et al., 2012 and Ahmed et al., 2013). Scientists are different in their attitudes regarding the mode of action of microorganisms on plant growth and development. Some opinions argue that they play an important role to fix $\mathrm{N}$, to solubilize $\mathrm{P}$ and $\mathrm{K}$, and to decompose cellulose. Others argue their effect to the production of plant growth materials. For example, the phosphate solubilizing bacteria play an important role in adjusting soil solubility by releasing the soluble form of $\mathrm{P}$ for plant absorbance. These bacteria are also known as phosphate dissolvers (El-Shaikh, 2005; Rodriguez and Fraga, 1999; Hassan, et al., 2012; and Ahmed et al., 2013). It has been reported that a small dosage of Phosphorein, potassiumage, rhizobacterin, and
Easternabiofert biofertilizers has the same effect as a bigger dosage of traditional nitrogen fertilizers (Tawfik, 2008). Han and Lee (2005) reported that phosphorein partially overcomes the problems of phosphate fixation in calcareous soil. Easternabiofert is a slow release biofertilizer that supply the plant with macro- and micronutrients gradually throughout the growing season (Adediran et al., 2004), resulting in a pronounced effect on plant growth and total yield, in comparison to traditional mixture of $\mathrm{N}, \mathrm{P}$, and $\mathrm{K}$ fertilizers (El-Gamal and Hammad, 2005). Rhizobacterin is another kind of biofertilizers that have high amount of symbiotic and non-symbiotic bacteria that fix nitrogen from the atmosphere.

This research was carried out to study the effect of some commercial bio-fertilizers, such as easterna biofert, and the mixture of phosphorein, potassiumage and rhizobacterin, mixed with different levels of mineral fertilizers on growth, yield, and fruit quality of sweet pepper grown under greenhouse conditions, in comparison to the recommended dosage of used traditional fertilizers.

\section{MATERIALS AND METHODS}

This study was performed in plastic greenhouses $(30 \mathrm{~m}$ length $\times 9 \mathrm{~m}$ width $\times 3.25 \mathrm{~m}$ height $)$ at the experimental farm of the Faculty of Agriculture, Tanta University, Tanta, Egypt, during 2013/2014 and 2014/2015 seasons. Different levels of mineral fertilizers (50 and 75 of recommended dose 'RD') with some biofertilizers i.e. easterna biofert (commercial biofertilizer), or the mixture of rhizobacterin, phosphorein and potassiumage were compared with $100 \%$ of recommended dose of mineral fertilizers without biofertilizers.

The analysis of the experimental soil was according to Ryan et al. (1996), was as follow; 


$$
\begin{aligned}
& \text { Sand }=15.65 \% \\
& \text { Silt }=39.87 \% \\
& \text { Clay }=44.48 \% \\
& \text { pH }=7.93
\end{aligned}
$$

Available $\mathrm{N}=49.1 \mathrm{mg} / 100 \mathrm{~g}$

Available $\mathrm{P}=6.9 \mathrm{mg} / 100 \mathrm{~g}$

Available $\mathrm{K}=161.96 \mathrm{mg} / 100 \mathrm{~g}$

\section{Plant material:}

Sweet pepper seedlings (Capsicum annuum, L. cv. Gideon F1 hybrid) were transplanted in the greenhouse on August $15^{\text {th }}$ and $14^{\text {th }}$ during 2013 and 2014 seasons, respectively, at $50 \mathrm{~cm}$ - apart in both sides of the ridges.

\section{Experiment:}

According to the manufacturer's recommendations, Easterna biofert $\left(15 \mathrm{ml} / \mathrm{m}^{3}\right.$ water/ greenhouse) was mixed with 50 and $75 \%$ RD of mineral fertilizers, and added weekly through drip Irrigation during both seasons. The source of Easterna biofert was El-Sharkia Company for Agricultural \& Industrial Development, Egypt. It contains $10 \%$ digested protein and amino acids (vegetable source), 6\% carbohydrate materials and derivatives (vegetable source), $6 \%$ organic potassium, $6 \%$ vital and normal phosphorus, $4 \%$ organic nitrogen (vegetarian protein source), $1 \%$ normal magnesium, $10 \%$ calcium, $1 \%$ micro-elements (iron, zinc, manganese and copper) grapple.

Three different types of biofertilizers (Phosphorin containing phosphate dissolver bacteria, potassiumage and rhizobacterin containing Azotobacter nitrogen fixing bacteria) were mixed and used with 50, and 75 $\%$ RD mineral fertilizers. The recommended mineral fertilizers were added through drip Irrigation $\left(\mathrm{g} / \mathrm{m}^{3}\right.$ water/greenhouse), as follows: $350 \mathrm{~g}$ ammonium nitrate (33\%), $200 \mathrm{ml}$ phosphoric acid (85\%), $300 \mathrm{~g}$ potassium sulfate (48\%), $50 \mathrm{~g}$ magnesium sulfate ( $\mathrm{V} \%$ ), and 200 g calcium nitrate $(15.5 \%)$, following the RD of Egyptian Ministry of Agriculture.

To enrich sweet pepper seedling roots before transplanting, roots were dipped in water contains a mixture of biofertilizers suspension and Arabic gum for 3 minutes (biofertilizers were added at $3 \mathrm{~kg} / \mathrm{fed}$.)

The experiment had five treatments as follows:

T1: Recommended dose (RD)of mineral fertilizers.

$\mathrm{T} 2: 50 \% \mathrm{RD}+$ Easterna biofert $(50 \% \mathrm{RD}+\mathrm{Es})$

$\mathrm{T} 3: 50 \% \mathrm{RD}+$ Phosphorein + Potassiumage + Rhizobacterin (50\% RD + Bio)

T4: 75\% RD + Easterna biofert (75\% RD + Es)

T5:75\%RD + Phosphorein + Potassiumage +

Rhizobacterin (75\% RD + Bio)

Four replicates were arranged in a randomized complete blocks design, with four replicates per treatment. The plot area was $30 \mathrm{~m}^{2}$ contained 1 row (30 $\mathrm{m}$ length $\times 1 \mathrm{~m}$ width). Greenhouse management practices for sweet pepper production were performed upon need.

\section{Collected data:}

Plant characteristics; five plants from each plot were randomly selected, at 90 days from transplanting, to measure the number of leaves per plant, plant height, number of branches per plant, leaf area /plant $\left(\mathrm{cm}^{2}\right)$, fresh and dry weight per plant (\%).

Yield and fruit quality; freshly harvest fruits were weighted to calculate early yield $\left(\mathrm{kg} / \mathrm{m}^{2}\right)$ and total yield

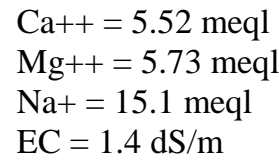

$\left(\mathrm{kg} / \mathrm{m}^{2}\right)$. Early yield was determined from the first to the six harvests (early November - late December) in each season. Total yield $\left(\mathrm{kg} / \mathrm{m}^{2}\right)$ in each plot was recorded, and then the total fruit weight per square meter was calculated from the first harvest until the end of May taking into account that the harvest window (Novemeber - May) included 17 harvest times. Fruit length, fruit diameter, fruit dry weight per plant (\%) and fruits number/ plant were calculated for each plot during the entire season.

Chemical composition; all chemical constituent and phytohormones were performed after 95 day of transplanting. photosynthetic pigments as well as carotenoids were colorimetrically analyzed in the fourth leaf of randomly selected plants following Inskeep and Bloom (1985) method. At the harvest time nutrition minerals \% were assayed in fruits following methods described by Horneck and Hanson (1998); Horneck and Miller(1998) and Sandell (1950). Total carbohydrates were determined in fruits according to (Dubios et al.,1956). Total soluble solids (TSS) were analyzed using a hand refractometer. Vitamin $\mathrm{C}, \mathrm{NO}_{3}$ and titratable acidity were determined in fruits according to (A.O.A.C., 1990) methods. Endogenous phytohormones wereonly determined in the second season quantitatively by High- Performance Liquid Chromatography (HPLC) procedure Koshioka et al. (1983) for gibberellic acid $\left(\mathrm{GA}_{3}\right)$, auxin (IAA), and abscisic acid (ABA), while, cytokinins were determined according to (Nicander et al., 1993). Leaves as well as fruits crude protein content was calculated using the following equation: Crude protein $(\%)=$ Total nitrogen $\times 6.25$

\section{Statistical analysis:}

Data were analyzed using MSTATC software program adopted by Bricker (1991) to calculate means, variance and standard error. LSD (least significant difference) was used for means separation at 5\% level according to Snedecor and Cochran (1990).

\section{RESULTS}

\section{Vegetative growth}

Plant growth characteristics were affected significantly by the application of mineral fertilizers and biofertilizers mixture (Table 1).

The most pronounced effect was related to the following descending order of treatments; $100 \% \mathrm{RD}$, $75 \% \mathrm{RD}+\mathrm{Bio}$, and then $75 \% \mathrm{RD}+$ Es with no significant differences among the three treatments.

\section{Photosynthetic pigments}

Data presented in Table 2 clearly indicate that chlorophyll a, chlorophyll b, total chlorophyll $(\mathrm{a}+\mathrm{b})$, and carotenoids were positively affected by the fertilization treatment during both seasons. Like vegetative growth characteristics, the values of photosynthetic pigments were responded positively to $100 \% \mathrm{RD}$, then $75 \% \mathrm{RD}+$ Bio, followed by $75 \% \mathrm{RD}+$ Es, whereas the lowest 
values were related to $50 \% \mathrm{RD}$ with Bio or ES. These results were significant in both seasons.

Table 1. Effect of different levels of mineral fertilizers mixed with some biofertilizers on vegetative growth characteristics of sweet pepper during 2013/2014 and 2014/2015 seasons.

\begin{tabular}{|c|c|c|c|c|c|}
\hline Treatments & $\begin{array}{l}\text { Plant } \\
\text { height } \\
(\mathrm{cm})\end{array}$ & $\begin{array}{l}\text { No. of } \\
\text { branches/ } \\
\text { plant }\end{array}$ & $\begin{array}{ll}\text { Leaf } & \text { No. of } \\
\text { area / leaves/ } \\
\text { plant } \\
\left(\mathrm{cm}^{2}\right)\end{array}$ & $\begin{array}{l}\text { Plant } \\
\text { Fresh } \\
\text { weight } \\
\text { (g) } \\
\end{array}$ & $\begin{array}{l}\text { Plant } \\
\text { Dry } \\
\text { weight } \\
(\%)\end{array}$ \\
\hline \multicolumn{6}{|c|}{$2013 / 2014$ season } \\
\hline $50 \% \mathrm{RD}+\mathrm{Es}$ & 75.67 & 9.34 & 692.7681 .02 & 260.9 & 17.01 \\
\hline $50 \% \mathrm{RD}+\mathrm{Bio}$ & 78.47 & 9.51 & 708.8787 .56 & 256.2 & 17.04 \\
\hline $75 \% \mathrm{RD}+\mathrm{Es}$ & 88.99 & 13.03 & 843.4710 & 272.43 & 17.31 \\
\hline $75 \% \mathrm{RD}+\mathrm{Bio}$ & 89.41 & 12.99 & 856.231 & 270.2 & 17.23 \\
\hline $100 \% \mathrm{RD}$ & 93.23 & 13.81 & 891.25107 .31 & 279.3 & 17.39 \\
\hline L.S.D. $(P \leq 5 \%)$ & 4.69 & 0.91 & $49.86 \quad 6.41$ & 8.25 & 0.09 \\
\hline \multicolumn{6}{|c|}{$2014 / 2015$ season } \\
\hline $50 \% \mathrm{RD}+\mathrm{Es}$ & 82.79 & 9.79 & 701.2982 .21 & 272.21 & 16.93 \\
\hline $50 \% \mathrm{RD}+\mathrm{Bio}$ & 80.11 & 9.65 & 714.6783 & 275 & 16.98 \\
\hline $75 \% \mathrm{RD}+\mathrm{Es}$ & 94.96 & 13.83 & 869.4796 .87 & 295.87 & 17.18 \\
\hline $75 \% \mathrm{RD}+\mathrm{Bio}$ & 96.43 & 13.91 & 887.15101 .21 & 297.32 & 17.21 \\
\hline $100 \% \mathrm{RD}$ & 99.32 & 14.06 & 913.21104 .56 & 303.46 & 17.26 \\
\hline L.S.D. $(P \leq 5 \%)$ & 4.45 & 0.25 & $45.78 \quad 9.15$ & 9.98 & 0.11 \\
\hline \multicolumn{6}{|c|}{$\begin{array}{l}\text { Where: Es is Easterna biofert, RD: Recommended dose of mineral } \\
\text { NPK, Bio: Phosphorein + Potassiumage + Rhizobacterin }\end{array}$} \\
\hline \multicolumn{6}{|c|}{$\begin{array}{l}\text { Table 2.Effect of different levels of mineral fertilizers } \\
\text { mixed with some biofertilizers on } \\
\text { photosynthetic pigments and } N / P / K \text { content } \\
\text { in sweet pepper leaves during } 2013 / 2014 \text { and } \\
2014 / 2015 \text { seasons. }\end{array}$} \\
\hline
\end{tabular}

\begin{tabular}{|c|c|c|c|c|c|c|c|}
\hline reatments & $\frac{\pi}{\frac{\pi}{2}}$ & 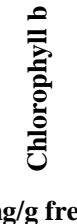 & 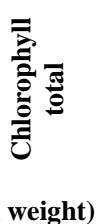 & 告 & (dry & y weigh & t \%) \\
\hline \multicolumn{8}{|c|}{$2013 / 2014$ season } \\
\hline $50 \% \mathrm{RD}+\mathrm{Es}$ & 0.589 & 0.307 & 0.896 & 0.393 & 2.11 & 0.387 & 3.99 \\
\hline $0 \% \mathrm{RD}+\mathrm{Bio}$ & 0.612 & 0.321 & 0.933 & 11 & 2.19 & 0.401 & 3.97 \\
\hline $75 \% \mathrm{RD}+\mathrm{Es}$ & 0.701 & 0.439 & 1.141 & 0.433 & 2.64 & 0.458 & 4.00 \\
\hline $75 \%$ RD+Bio & 0.706 & 0.452 & 1.158 & 0.541 & 2.71 & 0.462 & 4.07 \\
\hline $100 \%$ RD & 0.724 & 0.471 & 1.195 & 0.564 & 2.82 & 0.473 & 4.11 \\
\hline L.S.D. $(P \leq 5 \%)$ & 0.035 & 0.049 & 0.065 & 0.061 & 0.29 & 0.019 & N.S \\
\hline \multicolumn{8}{|c|}{$2014 / 2015$ season } \\
\hline $50 \% \mathrm{RD}+\mathrm{Es}$ & 0.582 & 0.355 & 0.937 & 0 & 2.03 & & 3.72 \\
\hline $50 \% \mathrm{RD}+\mathrm{Bio}$ & 0.602 & 0.381 & 0.983 & 0.433 & 2.07 & 0.425 & 3.75 \\
\hline $75 \% \mathrm{RD}+\mathrm{Es}$ & 0.701 & 0.463 & 1.164 & 0.559 & 2.58 & 0.470 & 3.79 \\
\hline $75 \% \mathrm{RD}+\mathrm{Bio}$ & 0.718 & 0.479 & 1.197 & 0.574 & 2.73 & 0.479 & 3.84 \\
\hline $100 \% \mathrm{RD}$ & 0.739 & 0.491 & 1.230 & 0.591 & 2.99 & 0.491 & 3.91 \\
\hline L.S.D. $(P \leq 5 \%)$ & 0.045 & 0.069 & 0.076 & 0.58 & 0.49 & 0.035 & N.S \\
\hline
\end{tabular}

Where: Es is Easterna biofert, RD: Recommended dose of mineral NPK, Bio: Phosphorein + Potassiumage + Rhizobacterin

\section{Phytohormones:}

Data in Table (3) indicated that application of $100 \%$ RD, $75 \%$ RD + Bio, and 75\% RD + Es increased the levels of auxins and cytokinins, but it did not affect the levels of gibberellins and abscisic acid in sweet pepper leaves during 2014/2015 season.

Yield parameters:

Data in Table 4 indicate that mineral and bio fertilization generally increased fruit dry weight percentage, fruit number per plant, fruit length and diameter, and early and total yield during both seasons.
The most pronounced effect was mainly related to the application of $100 \% \mathrm{RD}$, followed by $75 \% \mathrm{RD}+\mathrm{Bio}$, then $75 \% \mathrm{RD}+$ Es. This increase in fruit yield parameters may be a result of increasing in vegetative growth characteristics (Table 1) and photosynthetic pigments and chemical composition (Table 2), which affect plant growth and productivity. Same results were reported on some vegetable crops (Abdalla et al., 2001; Abdalla, 2002; El-Shaikh, 2005; Direkvandi et al., 2008; Ahmed, 2009; Midan and Sorial, 2011; Hassan et al. 2012 and Ahmed et al., 2013).

Table 3. Effect of different levels of mineral fertilizers mixed with some biofertilizers on phytohormones content in sweet pepper shoots during 2014/2015 season.

\begin{tabular}{lcccc}
\hline Treatments & Gibberellins & \multicolumn{3}{c}{$\begin{array}{c}\text { Auxins Cytokinins } \\
(\boldsymbol{\mu g} / \mathbf{1 0 g} \text { FW })\end{array}$} \\
& \multicolumn{5}{c}{$\begin{array}{c}\text { Abscisic } \\
\text { acid }\end{array}$} \\
\hline 50\%RD+ Es & 12.807 & 2.712 & 0.649 & 0.0989 \\
50\%RD+Bio & 12.799 & 2.757 & 0.653 & 0.0983 \\
75\%RD+ Es & 12.891 & 3.138 & 0.681 & 0.0964 \\
75\%RD+Bio & 12.974 & 3.159 & 0.687 & 0.0962 \\
100\%RD & 13.073 & 3.225 & 0.695 & 0.0951 \\
L.S.D. $(P \leq 5 \%)$ & N.S & 0.099 & 0.019 & N.S \\
\hline
\end{tabular}

Where: Es is Easterna biofert, RD: Recommended dose of mineral NPK, Bio: Phosphorein + Potassiumage + Rhizobacterin

Table 4. Effect of different levels of mineral fertilizers mixed with some biofertilizers on yield components of sweet pepper during 2013/2014 and 2014/2015 seasons.

\begin{tabular}{|c|c|c|c|c|c|c|}
\hline Treatments & $\begin{array}{l}\text { Fruit } \\
\text { No. / } \\
\text { plant }\end{array}$ & $\begin{array}{c}\text { Fruit } \\
\text { length } \\
(\mathrm{cm})\end{array}$ & $\begin{array}{c}\text { Fruit } \\
\text { diameter } \\
(\mathrm{cm})\end{array}$ & $\begin{array}{c}\text { Fruit } \\
\text { dry } \\
\text { weight } \\
(\%)\end{array}$ & $\begin{array}{c}\text { Early } \\
\text { yield } \\
(\mathrm{Kg} / \\
\left.\mathbf{m}^{2}\right)\end{array}$ & $\begin{array}{c}\text { Total } \\
\text { yield } \\
\left(\mathrm{Kg} / \mathbf{m}^{2}\right)\end{array}$ \\
\hline \multicolumn{7}{|c|}{$2013 / 2014$ season } \\
\hline $50 \% \mathrm{RD}+\mathrm{Es}$ & 29.88 & 11.1 & 5.18 & 8.09 & 0.337 & 4.89 \\
\hline $50 \%$ RD+Bio & 31. & & 5.24 & 8.23 & 0.381 & 5.09 \\
\hline $75 \% \mathrm{RD}+\mathrm{Es}$ & 41.99 & 14.91 & 7.39 & 9.17 & 0.699 & 8.63 \\
\hline $75 \% \mathrm{RD}+\mathrm{Bio}$ & 42.03 & 14. & 7. & 9.21 & 0.723 & 8.75 \\
\hline $100 \% \mathrm{RD}$ & 43.21 & 15.34 & 7.62 & 9.32 & 0.756 & 8.99 \\
\hline L.S.D. $(P \leq 5 \%)$ & 2.75 & 0.49 & 0.27 & 0.19 & 0.061 & 0.41 \\
\hline \multicolumn{7}{|c|}{$2014 / 2015$ season } \\
\hline $50 \% \mathrm{RD}+\mathrm{Es}$ & 31.9 & & & 7.92 & 0.376 & 5.23 \\
\hline $50 \% \mathrm{RD}+\mathrm{Bio}$ & 30.54 & 10.44 & 9 & 8.05 & 0.443 & 5.16 \\
\hline $75 \% \mathrm{RD}+\mathrm{Es}$ & 41.79 & 14.7 & 7.73 & 9.18 & 0.673 & 8.55 \\
\hline $75 \% \mathrm{RD}+\mathrm{Bio}$ & 43.47 & 14.8 & 7.86 & 9.16 & 0.698 & 8.79 \\
\hline $100 \% \mathrm{RD}$ & 44.76 & 15.12 & 8.02 & 9.27 & 0.728 & 8.96 \\
\hline L.S.D. $(P \leq 5 \%)$ & 3.15 & 0.41 & 0.33 & 0.15 & 0.059 & 0.45 \\
\hline
\end{tabular}

Where: Es is Easterna biofert, RD: Recommended dose of mineral NPK, Bio: Phosphorein + Potassiumage + Rhizobacterin

\section{Chemical composition of leaves and fruits:}

Leaf contents of $\mathrm{N}$ and $\mathrm{P}$ were significantly affected by applications of bio and mineral fertilizers, while $\mathrm{K}$ concentrations were insignificant, in both seasons (Table 2). Mineral and bio fertilization were significantly increased fruit chemical composition, such as vitamin $\mathrm{C}, \mathrm{TSS}, \mathrm{N}, \mathrm{P}, \mathrm{K}, \mathrm{NO}_{3}$ content, crude protein and total carbohydrates but there were no effect on titratable acidity during both seasons. The most pronounced effect was mainly related to the application of $100 \%$ RD, $75 \%$ RD + Bio, and 75\% RD + Es (Table 5 and 6). 
Table 5. Effect of different levels of mineral fertilizers mixed with some biofertilizers on chemical composition of fruits of sweet pepper during 2013/2014 and 2014/2015 seasons

\begin{tabular}{|c|c|c|c|c|c|}
\hline Treatments & $\mathbf{N}$ & $\begin{array}{l}\text { P } \\
\text { (Dry } \\
\mathbf{2 0}\end{array}$ & $\begin{array}{c}\text { K } \\
\text { weight } c \\
13 / 2014\end{array}$ & $\begin{array}{l}\text { Crude } \\
\text { protein } \\
\text { eason }\end{array}$ & $\begin{array}{c}\text { Total } \\
\text { carbohydrates } \\
\text { (mg/g dry weight) }\end{array}$ \\
\hline $50 \% \mathrm{RD}+\mathrm{Es}$ & 1.04 & 0.314 & 1.69 & 6.50 & 601.87 \\
\hline $50 \% \mathrm{RD}+\mathrm{Bio}$ & 1.16 & 0.305 & 1.81 & 7.25 & 618.23 \\
\hline $75 \% \mathrm{RD}+\mathrm{Es}$ & 1.55 & 0.363 & 1.207 & 9.69 & 681.99 \\
\hline $75 \%$ RD+Bio & 1.56 & 0.376 & 2.04 & 9.75 & 692.51 \\
\hline $100 \% \mathrm{RD}$ & 1.69 & 0.391 & 2.13 & 10.56 & 704.34 \\
\hline L.S.D. $(P \leq 5 \%)$ & 0.22 & 0.032 & 0.15 & 0.89 & 29.4 \\
\hline \multicolumn{6}{|c|}{$2014 / 2015$ season } \\
\hline $50 \% \mathrm{RD}+\mathrm{Es}$ & 1.11 & 0.325 & 1.79 & 6.94 & 592.42 \\
\hline $50 \% \mathrm{RD}+\mathrm{Bio}$ & 1.17 & 0.343 & 1.91 & 7.31 & 601.31 \\
\hline $75 \% \mathrm{RD}+\mathrm{Es}$ & 1.63 & 0.407 & 2.18 & 10.19 & 686.54 \\
\hline $75 \% \mathrm{RD}+\mathrm{Bio}$ & 1.59 & 0.419 & 2.24 & 9.94 & 698.82 \\
\hline $100 \% \mathrm{RD}$ & 1.72 & 0.438 & 2.32 & 10.75 & 714.87 \\
\hline L.S.D. $(P \leq 5 \%)$ & 0.08 & 0.042 & 0.19 & 0.82 & 35.9 \\
\hline
\end{tabular}

Where: Es is Easterna biofert, RD: Recommended dose of mineral NPK, Bio: Phosphorein + Potassiumage + Rhizobacterin

\section{DISCUSSIONS}

This positive effect on vegetative growth characteristics is mainly due to the effect of these components on photosynthetic pigments, chemical composition (Table 2), and endogenous phytohormones (Table 3). The combination of 50\% RD with Bio or Es showed the lowest growth characteristics values with no significant differences between both treatments. Similar trends were noticed by Ahmed (2009) on onion, Midan and Sorial (2011) on snap bean, Hassan et al. (2012) on coriander and Ahmed et al. (2013) on sweet pepper.

It can be indicated from the results that mineral and bio-fertilization generally improved the growth characteristics and productivity of sweet pepper plants grown under greenhouses conditions. The most pronounced effect of fertilization was mainly related to the application of $100 \%$ RD of mineral fertilizer, then $75 \%$ RD of mineral fertilizer mixed with phosphorein, potassiumage and rhizobacterin, and the application of $75 \%$ RD of mineral fertilizer combined with Easterna biofert. It is well known that the chemical fertilizers promote plant growth through the role of nitrogen in protein synthesis and increasing the meristimatic activity. Marschner (1995) stated that changing in nitrogen supply to plant roots can affect the levels of plant phytohormones, and therefore affect plant growth and development. Phosphorus is an essential component of ATP, ADP, and phosphoproteins (Mahfouz and Sharaf-Eldin, 2007; Hassan, 2009; Hassan et al., 2012 and Ahmed et al., 2013).Easterna biofertilizer promote plant growth and development, and increase productivity of sweet pepper under greenhouses conditions, and this could be attributed to the effect of non symbiotic $\mathrm{N}_{2}$ fixing and phosphate solubilizing bacteria through phytohormones synthesis, $\mathrm{N}_{2}$ fixation, reduction of root membrane potential, and the synthesis of some enzymes, such as ACC deaminase that modulate the level of plant hormones, solubilize inorganic phosphate, and mineralize organic phosphate to increase phosphorus availability to the plant
(Rodriguez and Fraga,1999). The excessive number of microorganisms in the soil had positively converted the unavailable form of nutrients to the available form. In addition, they also produce growth substances that resulte in more nutrients absorption (Gomaa and Abou-Aly, 2001). The non-symbiotic $\mathrm{N}_{2}$ fixing bacteria produce adequate amounts of IAA and cytokinins that increase the root surface area and nutrients uptake (Rodriguez and Fraga, 1999). Phosphate solubilizing bacteria release organic and inorganic acids that reduce soil $\mathrm{pH}$ and increase phosphorus and other nutrients availability to the plants (Singh and Kapoor, 1999). Micro-organisms play an essential role in the natural phosphorus cycle through the cyclic oxidation and reduction of phosphorus compounds (Ohtake et al., 1996). Jagnow et al., (1991) stated that the positive effect of biofertilizers on plant growth and development may be attributed to their content of Azotobacter and Azospirillum, which produce adequate amounts of IAA and cytokinines increasing root surface area and nutrients uptake.

Table 6. Effect of different levels of mineral fertilizers mixed with some biofertilizers on chemical composition of fruits of sweet pepper during $2013 / 2014$ and $2014 / 2015$ season

\begin{tabular}{|c|c|c|c|c|}
\hline Treatments & 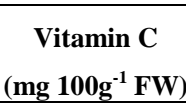 & $\begin{array}{c}\mathrm{NO}_{3} \\
\left.\mathrm{~g} \mathrm{~kg}^{-1} \mathrm{FW}\right)\end{array}$ & $\begin{array}{l}\text { TSS } \\
(\%)\end{array}$ & $\begin{array}{c}\text { Titratabl } \\
\text { e acidity } \\
(\%)\end{array}$ \\
\hline \multicolumn{5}{|c|}{$2013 / 2014$ season } \\
\hline $50 \% \mathrm{RD}+\mathrm{Es}$ & 99.3 & 8.26 & 4.15 & 0.362 \\
\hline $50 \% \mathrm{RD}+\mathrm{Bio}$ & 101.5 & 8.31 & 4.23 & 0.353 \\
\hline $75 \% \mathrm{RD}+\mathrm{Es}$ & 117.9 & 10.02 & 4.71 & 0.385 \\
\hline $75 \% \mathrm{RD}+\mathrm{Bio}$ & 1194 & 10.11 & 4.78 & 0.391 \\
\hline $100 \% \mathrm{RD}$ & 123.7 & 13.65 & 4.99 & 0.399 \\
\hline L.S.D. $(P \leq 5 \%)$ & 7.5 & 0.15 & 0.29 & NS \\
\hline \multicolumn{5}{|c|}{$2014 / 2015$ season } \\
\hline $50 \% \mathrm{RD}+\mathrm{Es}$ & 102.7 & 8,97 & 3.99 & 0.379 \\
\hline $50 \% \mathrm{RD}+\mathrm{Bio}$ & 105.3 & 9.01 & 3.96 & 0.372 \\
\hline $75 \% \mathrm{RD}+\mathrm{Es}$ & 124.8 & 10.75 & 4.65 & 0.391 \\
\hline $75 \% \mathrm{RD}+\mathrm{Bio}$ & 125.2 & 10.96 & 4.73 & 0.397 \\
\hline $100 \% \mathrm{RD}$ & 127.6 & 14.09 & 4.91 & 0.408 \\
\hline L.S.D. $(P \leq 5 \%)$ & 4.9 & 0.19 & 0.31 & NS \\
\hline
\end{tabular}

Where: Es is Easterna biofert, RD: Recommended dose of mineral NPK, Bio: Phosphorein + Potassiumage + Rhizobacterin

\section{CONCLUSIONS}

It could be concluded that applying $75 \%$ of the RD of mineral fertilizers with Phosphorein, Potassiumage and Rhizobacterin or with Easterna biofert can improve sweet pepper production under greenhouses conditions. Using biofertilizers with mineral fertilizers will be reflected on a positive reduction in total fertilization cost, risk of nitrate accumulation in the plant edible portion, and environmental pollution. However, reducing the RD to $50 \%$ reduces plant yield, but improve fruit characteristics that will be reflected on price.

\section{REFERENCES}

Abdalla, A.M. (2002). Effect of bio- and mineral phosphorus fertilizer on the growth, productivity and nutritional value of faba bean. Egypt. J. Hort., 29(2): 187-203. 
Abdalla, A.M.; F.R. Rizk and S.M. Adam (2001). The productivity of pepper plants as influenced by some biofertilizer treatments under plastic house conditions. Bull. Fac. Agric., Cairo Univ., 52: 625-640.

Adediran, J.A; L.B. Taiwo; M.O. Acande; R.A. Sobulo and O.J. Idown (2004). Application of organic and inorganic fertilization for sustainable maize and cowpea yields in Nigeria, J. Plant Nutrition, 27(7): 1163-1181.

Ahmed M.E.M. ; A. A. Abd-Ellatif and A.A. Al-Araby (2013). Growth, yield and fruit quality of sweet pepper plants as affected by some bio organic and mineral fertilizers application. Life Sci. J., 10(4): 2756- 2766.

Ahmed, M.E.(2009). Effect of some bio and mineral fertilization levels on the growth, productivity and storability of onion. Annals Agric. Sci., Ain Shams Univ., 54 (2): 427-436.

A.O.A.C. (1990). Official Methods of Analysis of the Association of Official Agriculture Chemists. Published by Association of Official Agriculture Chemists, $13^{\text {th }}$ Ed. Washington, D.C., USA.

Bricker, B. (1991). MSTATC: A micro computer program from the design management and analysis of agronomic research experiments. Michigan State University.

Direkvandi, S.; N.A. Ansari and F.S. Dehcordie (2008). Effect of different levels of nitrogen fertilizer with two type of bio- fertilizers on growth and yield of two cultivars of tomato (Lycopersicon esculentum, Mill). Asian J. of Plant Sci., 7(8): 757-761.

Dubois, M.; K.A. Gilles; J.K. Hamilton; P.A. Rebens and F. Smith (1956). Colorimetric methods for determination sugars and related substances. Annals. Chem. Soc., 46: 1662-1669.

El-Gamal, S. and S. Hammad (2005). Response of Helianthus tuberosus, L. to organic and bioorganic fertilizers. Arab. Univ. J. Agric. Sci. Ain shams Univ. Cairo, Egypt, 13(3): 609-623.

El-Shaikh, K.A.(2005). Growth and yield of onion as affected by bio fertilization, application of nitrogen and phosphorus fertilizers under South Valley conditions. Assiut G. Agric. Sci., 36(1): 37-50.

Gomaa, A.O. and H.E. Abou-Aly (2001). Efficiency of biofertilization in the presence of inorganic and organic fertilizers on growth, yield and chemical constituents of anise plant (Pimpinella anisum, L.). Proc. Arabian Hort. Conf., Ismailia, Egypt, 73-80.

Han, H.S. and K.D. Lee (2005). Phosphate and potassium solubilizing bacteria effect on mineral uptake, soil availability and growth of egg plant. Research J. of Agric. and Biological Sci., 1(2): 176-180.

Hassan, F.A. (2009). Response of Hibiscus sabdariffa, L. plant to some bio fertilization treatments. Annals Agric. Sci. Ain Shams Univ. Cairo., 54(2):437-446.
Hassan, F.A, E.F. Ali and S.A. Mahfouz (2012). Comparison between different fertilization sources, irrigation frequency and their combinations on the growth and yield of Coriander plant. Aust. J. Basic \& Appl. Sci., 6(3): 600-615.

Horneck, D.A. and D. Hanson (1998). Determination of potassium and sodium by flame Emission spectrophotometry. In hand book of reference methods for plant analysis, e.d Kolra, Y. P.(ed), pp: $153-155$.

Horneck, D.A. and R.O.Miller (1998). Determination of total nitrogen in plant tissue. In hand book of reference methods for plant analysis, e. d. Kolra, Y. P. (ed), pp: 73

Inskeep, W.P. and P.R. Bloom (1985). Extinction coefficients of chlorophyll a \& b in dimethylformade and $80 \%$ acetone. Plant Physiol, 77: 483-485.

Jagnow, G. ; G. Hoflich and K.H. Hoffman (1991). Inoculation of non-symbiotic rhizosphere bacteria. Possibilities of increasing and stabilizing yield. Angew Botanik, 65: 97-126.

Koshioka, M.; J. Harada; M. Noma; T. Sassa; K. Ogiama; J.S. Taylor S.B.; Rood; R.L. Legge and R.P. Pharis (1983). Reversed phase C18 high performance liquid Chromatography of acidic and conjugated gibberellins. J. Chromatgr, 256: 101-115.

Lyons, D.J.; G.E. Rayment; P.E. Nobbs and L. McCallum (1994). Nitrate and nitrite in fresh vegetables from Queensland, j. Sci. Food Agric., 64: 279-281.

Mahfouz, S.A. and M.A. Sharaf-Eldin (2007). Effect of mineral vs. biofertilizer on growth, yield and essential oil content of fennel (Foeniculum vulgare, Mill). International Agrophysics, 2007; 21: 361-366.

Marschner, H.(1995). Mineral nutrition in higher plants. $\left(2^{\text {nd }}\right.$ ed), Academic Press, London, New York, pp: 861 .

Midan S.A. and M.E. Sorial (2011). Some biofertilizers application in relation to growth, chemical constituents and yield of snap bean plants. Res.J. Agric. \& Biol. Sci., 2011;7(1): 142-149.

Nicander, B., U. Stahi, P.O. Bjorkman and E. Tillberg(1993). Immunoaffinity co-purification of cytokinins and analysis by high-performance liquid chromatography with ultraviolet spectrumdetection. Planta, 189: 312- 320.

Ohtake, H. ; K. Imazu; Y. Ambe; J. Kato and A. Kuroda (1996). Bacterial phosphonate degradation, phosphate oxidation and polyphosphate accumulation. Res. Conserv. and Recycling, 18: 125-134.

Rajput, JC and Y.R. Poruleker (1998). Capsicum in handbook of vegetable science and technology (D.K. Salunkhe and S.S. Kadam, eds.) Marcel Dekker, Inc. New York, p.721.

Rodriguez, H. and R. Fraga (1999). Phosphate solubilizing bacteria and their role in plant growth promotion. Biotech. Advan.,17: 319-339. 
Ryan, j.; S. Garabet; K. Harmsen and A.A. Rashid (1996). Soil and plant analysis manual. Adapted for the West Asia and North Africa Region. International Center for Agricultural Research in the Dry Areas, ICARDA, Aleppo, Syria. 140 pp.

Sandell, R. (1950). Colorimetric determination of traces of metal $2^{\text {nd }} E d$. Inter Since. Pub. Inc. New. York.

Singh, M; R.S. Ganesharao and S. Ramesh (2007). Effects of $\mathrm{N}$ and $\mathrm{K}$ on growth, herbage, oil yield and nutrient uptake patterns of rosemary under semi-arid tropical conditions, J. Hortic. Sci. Biotechnol., 82: 414- 419.

Snedecor, G.W. and W.G. Cochran (1990). Statistical methods. 8th Ed. Iowa state Univ. Press, Ames Iowa, U.S.A.
Tawfik, K.M.(2008). Evaluating the use of rhizobacterin on cowpea plants grown under salt stress. Research J. of Agric. and Biological Sci., 4(1): 26-33.

Singh, S. and K.K. Kapoor (1999). .Inoculation with phosphate- solubilizing microorganisms and vesicular arbuscular mycorrhizal fungus improves dry matter yield and nutrient uptake by wheat grown in sandy soil. Biol. Ferti. Soils, 28: $139-144$

\section{استجابة نباتات القلقل الحلو لاضافة مستويات مختلفة من السماد المعدنى مع بعض الاسمدة الحيوية.

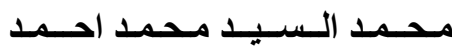 قسم البساتين- كلية الزراعة معل - جامعة طنطا - طنطا - مصر}

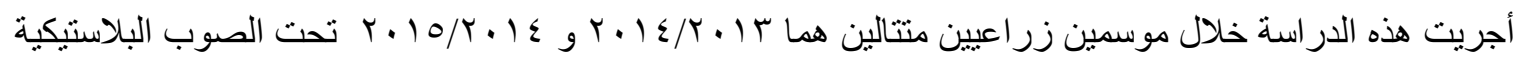

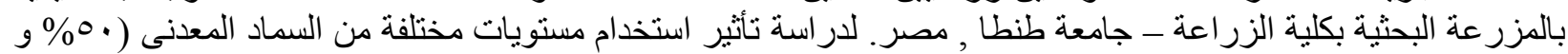

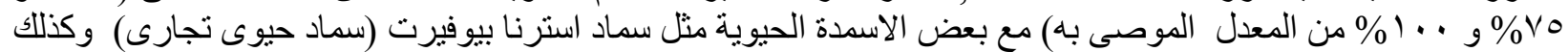

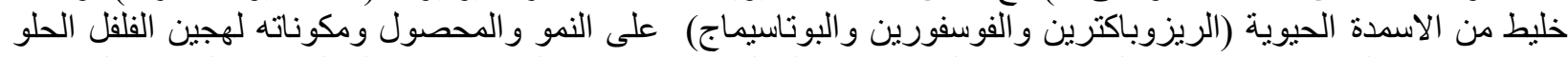

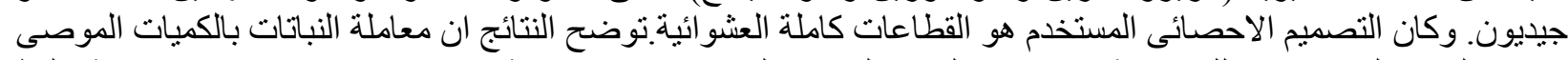

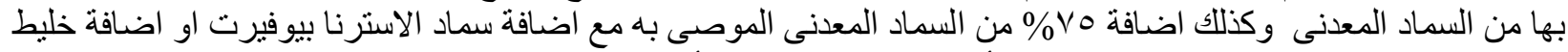

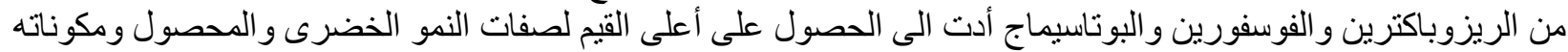

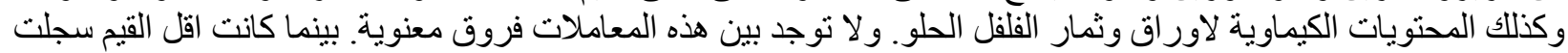

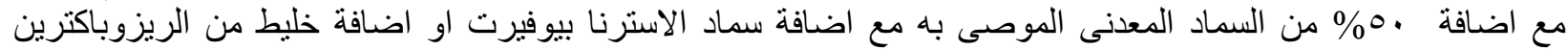

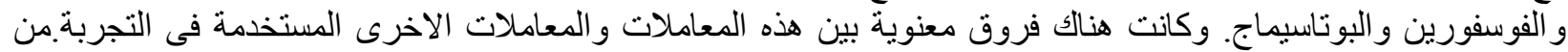

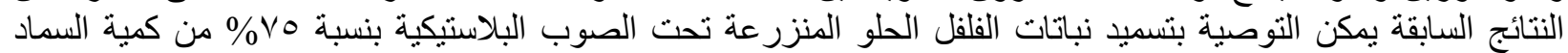

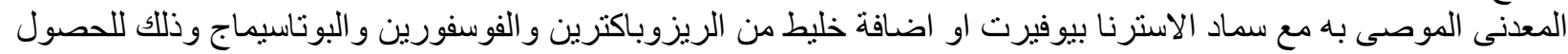

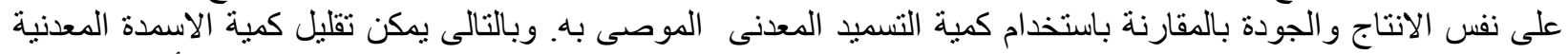

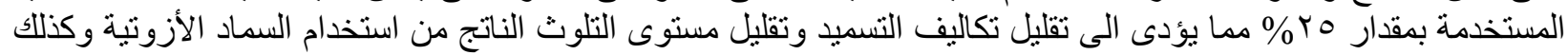
تقليل اثز تر اكم النترات. 